\title{
EFEKTIFITAS PENGGUNAAN MEDIA POSTER 3 DIMENSI SECARA DARING PADA MATERI TATA SURYA BERBASIS GOOGLE CLASSROOM UNTUK MENINGKATKAN PEMAHAMAN KONSEP FISIKA SISWA KELAS VII SMPN 1 WERA TAHUN PELAJARAN 2019/2020
}

\author{
Ferniawan ${ }^{1)}$, Johri Sabaryati ${ }^{1}$, Linda Sekar Utami $\left.{ }^{1}\right)$ \\ 1)Program Studi Pendidikan Fisika, FKIP, Universitas Muhammadiyah Mataram, Mataram, NTB, Indonesia \\ Corresponding author : Johri Sabaryati \\ E-mail : joyafarashy@gmail.com
}

Diterima 09 November 2020, Disetujui 15 November 2020

\begin{abstract}
ABSTRAK
Tujuan penelitian ini adalah untuk mengetahui efektifitas penggunaan media poster 3 dimensi secara daring pada materi tata surya berbasis Google Classroom guna meningkatkan pemahaman konsep fisika siswa kelas VII SMPN 1 WERA. Penelitian ini berupa penelitian True eksperimental dasing pretest dan post-test. Populasi penelitian adalah siswa kelas VII SMPN 1 WERA yang berlokasi di Desa Tawali, Kec. Wera, Kab. Bima, NTB. Pembelajaran yang digunakan ialah yang tidak menggunakan media poster 3 dimensi secara daring untuk kelas kontrol, untuk kelas eksperimen menggunakan media poster 3 dimensi secara daring. Sampel penelitian ialah kelas VII-1 sebagai kelas eksperimen dan kelas VII-2 sebagai kelas kontrol. Ada tiga tahap teknik pengumpulan data, yaitu tahap persiapan, tahap menentukan kemampuan awal sampel, dan tahap pelaksanaan tindakan. Instrumen penelitian berupa tes objektif, yakni uji validitas, uji realiabilitas, uji tingkat kesukaran, dan uji daya pembeda. Teknik analisis data yang digunakan ialah uji persyaratan analisis meliputi uji homogenitas dan uji normalitas. Serta uji hipotesis berupa uji-t. Diperoleh hasil perhitungan uji-t, pre-test thitung $=0,332$ dan tabel $=1,682$

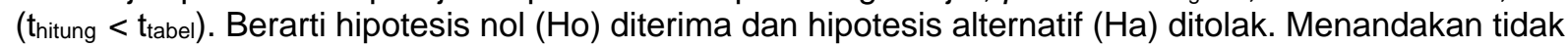
ada perbedaan kemampuan awal siswa. Nilai post-test thitung $=2,744$ dan tabel $=1,682$ (thitung $>$ trabel) berarti (Ho) ditolak dan $(\mathrm{Ha})$ diterima. Hasil analisis nilai uji $\mathrm{N}$-gain; kelas eksperimen sebesar 0,44 berkategori "sedang" dan kelas kontrol 0,22 berkategori "rendah". Akhirnya diperoleh bahwa efektifitas penggunaan Media Poster 3 Dimensi secara daring pada Materi Tata Surya berbasis Google Classroom dapat meningkatkan pemahaman konsep fisika siswa Kelas VII SMPN 1 WERA Tahun pelajaran 2019/2020.
\end{abstract}

Kata kunci : efektifitas penggunaan media poster 3 dimensi secara daring; pemahaman konsep

\begin{abstract}
The purpose of this study was to determine the effectiveness of the use of online 3-dimensional poster media on Google Classroom-based solar system material in order to improve understanding of the physics concepts of class VII students of SMPN 1 WERA. This research is in the form of true experimental research of pre-test and post-test. The study population was the VII grade students of SMPN 1 WERA located in Tawali Village, Kec. Wera, Kab. Bima, NTB. The lessons used are those that do not use online 3-dimensional poster media for the control class, for the experimental class using 3dimensional poster media online. The research sample was class VII-1 as the experimental class and class VII-2 as the control class. There are three stages of data collection techniques, namely the preparation stage, the stage of determining the initial capacity of the sample, and the stage of implementing the action. The research instrument was an objective test, namely the validity test, the reliability test, the difficulty level test, and the discriminating power test. The data analysis technique used is the analysis requirements test including the homogeneity test and normality test. As well as hypothesis testing in the form of t-test. Obtained the results of $t$-test calculations, pre-test $t=0.332$ and $\mathrm{t}$ table $=1.682$ ( $\mathrm{t}$ count $<\mathrm{t}$ table). It means that the null hypothesis $(\mathrm{Ho})$ is accepted and the alternative hypothesis $(\mathrm{Ha})$ is rejected. This indicates that there is no difference in students' initial abilities. The post-test value $t=2.744$ and $t$ table $=1.682$ (tcount $>$ table) means $(\mathrm{Ho})$ is rejected and $(\mathrm{Ha})$ is accepted. The results of the analysis of the $\mathrm{N}$-gain test value; the experimental class was 0.44 in the "medium" category and the control class was 0.22 in the "low" category. Finally, it was found that the effectiveness of using online 3-dimensional Media Posters on Google Classroom-Based Solar System Material can improve understanding of the physics concepts of Class VII students of SMPN 1 WERA in the 2019/2020 academic year.
\end{abstract}

Key words: the effectiveness of using online 3-dimensional poster media; understanding the concept. 


\section{PENDAHULUAN}

Pada tahun 2020 ini terjadi sebuah bencana yang tidak terduga yaitu merebaknya pandemi virus corona atau disebut juga Covid19. Pandemi Covid-19 tidak hanya melanda Indonesia, tetapi juga negara-negara lainnya seperti Amerika Serikat, Korea Selatana, Jepang, dan masih banyak negara lainnya. Pandemi Covid-19 pada mulanya berasal dari Kota Wuhan yang berada di Cina. Dengan penyebaran yang begitu luar biasa dahsyat, virus ini sudah membunuh puluhan ribu jiwa di seluruh dunia. Virus ini kecil, namun mematikan karena tidak terlihat dan penyebarannya yang begitu cepat. Pandemi Covid-19 memaksakan negara-negara yang terjangkit untuk melakukan lock down. Di Indonesia sendiri sudah diterapkan karantina wilayah dan PSBB (Pembatasan Sosial Berskala Besar). Akibatnya, perusahaan-perusahaan besar, sekolah, universitas, dan sektor lainnya terpaksa ditutup selama jangka waktu yang tidak ditentukan. Hal ini tentu menjadi masalah, khususnya bagi lembaga pendidikan. Dengan diliburkannya sekolah, otomatis kegiatan pembelajaran secara langsung tidak dapat dilaksanakan seperti biasanya.

Google Classroom menjadi salah satu solusi dari permasalahan di atas. Dengan adanya Google Classroom di tengah pandemi Covid-19 ini, siswa dan guru dapat berinteraksi di rumah aja. Guru tetap bisa memberikan tugas kepada siswa dan memantau perkembangan belajar siswa melalui smarthphone. Google Classroom sangat dibutuhkan dalam situasi pandemi Covid-19. Google Classroom hadir sebagai perangkat lunak pembelajaran daring yang dapat dimanfaatkan oleh semua kalangan.

SMPN 1 WERA adalah salah satu sekolah menengah pertama negeri yang ada di Desa Tawali, Kecamatan Wera, Kabupaten Bima, Nusa Tenggara Barat. Sekolah ini merupakan salah satu sekolah favorit di Kecamatan Wera. Meskipun berada di desa, sekolah ini telah mengenal aplikasi google classroom. Namun sayangnya, tidak semua guru telah menggunakan aplikasi ini. Oleh karena ini, penelitian ini dilakukan untuk mengetahui efektifitas penggunaan media poster 3 dimensi secara daring materi tata surya berbasis Google Classroom untuk meningkatkan pemahaman konsep fisika. Percobaan dilakukan guna mengetahui akibat dari penggunaan aplikasi Google Classroom dalam materi tata surya yang ditempuh oleh siswa kelas VII. Aplikasi ini digunakan ketika terjadinya hal-hal yang mengakibatkan proses kegiatan belajar mengajar di kelas tidak bisa dilaksanakan.

Berdasarkan hasil survei, juga diketahui bahwa faktor penyebab lainnya ialah kendala dalam menggunakan media belajar yang sesuai dengan keadaan siswa. Seiring dengan perkembangan teknologi dan informasi yang semakin pesat, siswa pun mengikuti perkembangan tersebut, baik dalam lingkungan masyarat maupun akademik. Siswa membutuhkan media belajar yang kreatif dan inovatif. Salah satu media yang dapat digunakan ialah media poster 3 dimensi. Poster dapat dimanfaatkan sebagai media dalam pembelajaran IPA fisika. Sementara di kelas VII SMPN 1 WERA Tahun pelajaran 2019/2020 belum menggunakan media poster dalam kegiatan belajar mengajar, khususnya pada materi tata surya.

Oleh karena itu, peneliti tertarik melakukan penelitian yang berjudul "Efektifitas Penggunaan Media Poster 3 Dimensi Secara Daring pada Materi Tata Surya Berbasis Google Classroom untuk Meningkatkan Pemahaman Konsep Fisika Siswa Kelas VII SMPN 1 WERA Tahun pelajaran 2019/2020".

\section{METODE PENELITIAN Metode Penelitian}

Metode penelitian yang digunakan adalah metode kuantitatif. Teknik pengambilan sampel pada umumnya dilakukan secara random. Pengumpulan data menggunakan instrumen penelitian. Data bersifat kuantitatif statistik.

\section{Jenis Penelitian}

Jenis penelitian ini adalah penelitian True Eksperimenntal Design (eksperimental yang betul- betul) karena pada desain peneliti dapat mengontrol semua variabel yang mepengaruhi jalanya eksperimen.

Penelitian ini diawali dengan melakukan pre-test untuk mengetahui kemampuan awal dari populasi. Kemudian ditentukan kelas sampel diberikan perlakuan yang berbeda dengan model pembelajaran yang akan digunakan adalah penggunaan media poster 3 dimensi secara daring pada materi tata surya berbasis google classroom sebagai kelas eksperimen dan model pembelajaran secara secara langsung digunakan pada kelas kontrol. Untuk mengatahui perbedaan hasil dari penggunaan masing-masing dilakukan posttest di akhir pertemuan. Desain penelitian ditunjukan dengan tabel 1 . sebagai berikut:

Tabel 1. Desain penelitian 


\begin{tabular}{llll}
\hline Kelas & $\begin{array}{l}\text { Pre- } \\
\text { test }\end{array}$ & Treatment & $\begin{array}{l}\text { Post- } \\
\text { test }\end{array}$ \\
\hline Eksperimen & $\mathrm{O}_{1}$ & $\mathrm{X}$ & $\mathrm{O}_{2}$ \\
Kontrol & $\mathrm{O}_{3}$ & - & $\mathrm{O}_{4}$
\end{tabular}

Keterangan:

$X=$ perlakuan kusus menggunakan media poster 3 dimensi secara daring pada materi tata surya berbasis google classroom

$\mathrm{O}_{1}=$ hasil pre-test kelas eksperimen sebelum diberikan perlakuan

$\mathrm{O}_{2}=$ hasil post-test kelas eksperimen setelah diberikan perlakuan

$\mathrm{O}_{1}=$ hasil pre-test kelas kontrol tidak diberikan perlakuan

$\mathrm{O}_{1}=$ hasil post-test kelas eksperimen tidak diberikan perlakuan (Sugiyono, 2015:7678)

\section{Populasi dan Sampel Penelitian \\ Populasi penelitian}

Populasi dalam penelitian ini adalah siswa kelas VII SMPN 1 WERA yang terdiri dari siswa kelas VII-1 Berjumlah 21 orang, VII -2 Berjumlah 24 orang, dan VII-3 Berjumlah 19 orang.

\section{Sampel Penelitian}

Sampel penelitian ditentukan dengan teknik Random sampling. Kelas eksperimen dan kelas kontrol di tentukan masing masing satu kelas yaitu kelas VII-1 sebagai kelas eksperimen dan kelas VII-2 sebagai kelas kontrol. Kelas eksperimen akan melakukan pembelajaran dengan menggunakan model pembelajaram penggunaan media poster 3 dimensi secara daring pada materi tata surya berbasis google classroom, sedangkan kelas kontrol menggunakan model pemebelajaran langsung.

\section{Variabel Penelitian}

Variabel dalam penelitian ini terdiri dari variabel bebas dan variabel terikat. Adapun yang menjadi variabel dalam penelitian ini adalah efektifitas penggunaan media poster 3 dimensi secara daring pada materi tata surya berbasis google classroom sebagai variabel bebas sedangkan pemahaman konsep fisika siswa sebagai variabel terikat.

\section{Perencanaan Penelitian}

Adapun hal-hal yang dilakukan dalam perencanaan penelitian sebagai berikut:

1. Menetapkan kelas kontrol atau eksperimen secara random.

2. Menyusun perangkat pembelajaran.

3. Menyusun item soal yang akan di uji instrumen.

4. Melakukan uji instrumen soal.

\section{Pelaksanaan penelitian}

Adapun hal-hal yang dilakukan dalam pelaksanaan penelitian sebagai berikut:

1. Melakukan pre-test dan post-test pada kelas eksperimen dan kelas kontrol.

2. Melaksanakan proses pembelajaran dengan model pembelajaran yang berbeda.

3. Pada kelas eksperimen meneriman pembelajaran dengan menggunakan model pembelajaran penggunaan media poster 3 dimensi secara daring pada materi tata surya berbasis google classroom, dan kelas kontrol menggunakan model pembelajaran langsung.

\section{Pelaksanaan Evaluasi}

Adapun hal-hal yang dilakukan dalam pelaksanaan evaluasi sebagai berikut:

1. Melakukan Post-Test pada kelas eksperimen dan kelas kontrol.

2. Melakukan uji hipotesi.

3. Uji N-gain

\section{Instrumen Penelitian}

Instrumen penelitian ini hanya menggunakan soal tes. Dalam penelitian ini dibuat dalam dua kelompok tes, tes pertama 30 soal untuk pre-test dan post-test. Kemudian dilakukan 4 jenis uji untuk memperoleh soal yang valid, releabilitas, tingkat kesukaran dan daya beda.

\section{Teknik Pengumpulan Data Uji Validitas}

Menguji tingkat validitas instrumen didahului dengan menguji cobakan instrumen terlebih dahulu. Dengan langkah ini instrumen dilakukan pada siswa kelas IX SMPN 1 WERA yang pernah belaja materi tata surya. Menurut Arikunto (2013:93), untuk menguji kevalidan butir soal yang akan digunakan korelasi point biserial karena menggunakan insttumen tes berupa soal pilihan ganda dan menggunakan skor (1 dan 0). Rumus korelasi point biserial sebagai berikut:

Keterangan:

$$
\gamma p b i=\frac{\mathrm{Mp}-\mathrm{Mt}}{\mathrm{St}} \sqrt{\frac{P}{q}}
$$

$$
\begin{aligned}
\gamma \mathrm{pbi}= & \text { koefisien korelasi biserial } \\
\mathrm{Mp}= & \text { rerata skor dari subjek-subjek } \\
& \text { yang menjawab betul item yang } \\
& \text { dicari validitasnya } \\
\mathrm{Mt}= & \text { rerata skor soal } \\
\mathrm{St} \quad= & \text { standar deviasi dari skor total } \\
\mathrm{P} \quad & \text { proporsi siswa yang menjawab } \\
& \text { benar } \\
\mathrm{Q} \quad \text { proporsi siswa yang menjawab } & \text { salah }
\end{aligned}
$$




\section{Uji Reliabilitas}

Realibilitas berhubung dengan masalah kepercayaan atau keterandalan tes dikatakan mempunyai taraf kepercayaan yang tinggi ( reliable) jika tes tersebut dapat memberikan hasil yang tepat. terdapat beberapa teknik yang dapat digunakan untuk menguji area beli beli tas instrumen salah satu dengan cara menggunakan rumus Kuder Richardson 20

dengan :

$$
r_{11}=\left(\frac{k}{k-1}\right)\left(\frac{s^{2}-\Sigma p q}{s^{2}}\right)
$$

Keterangan:

$$
s_{t}^{2}=\frac{\sum x_{t}^{2} \frac{\left(\sum x_{t}^{2}\right)}{N}}{N}
$$

$r_{11}=$ koefisienn reabilitas internal seluruh item

$\mathrm{K}=$ jumlah item dalam insrumen

$\mathrm{P}_{\mathrm{iq}} \mathrm{i}=$ jumlah hasil perkaalian $\mathrm{p}$ dan $\mathrm{q}$

$s_{t}^{2}=$ varians total

$X_{t}=$ skor total item soal

Dilihat dari hasil perhitungan, akan diperoleh nilai koefisien korelasi $r_{11}$ agar diketahui tinggi rendahnya koefisien tersebut. nilai korelasi $r_{11}$ yang diperoleh dikonsultasikan ke tabel harga kritik $r$ Product Moment dengan Taraf signifikan $5 \%$ Jika harga rhitung $>$ rtabel produk moment maka harga rhitung (nilai varians butir? variasi total) tersebut dikatakan reliabel (Arikunto, 2013:115).

\section{Taraf}

\section{Kesukaran}

Menurut Arikunto (2013:223), rumus yang digunakan untuk mencari taraf kesukaran soal adalah sebagai berikut:

Keterangan:

$$
P=\frac{B}{J S}
$$

$$
\begin{aligned}
& \mathrm{P}=\text { indeks kesukaran } \\
& \mathrm{B}=\text { banyaknya siswa yang } \\
& \text { menjawab soal dengan benar } \\
& \mathrm{JS}=\text { jumlah seluruh siswa } \\
& \text { peserta tes }
\end{aligned}
$$

Berdasarkan ketentuan yang sering diikuti, indeks kesukaran diklasifikasikan sebagai berikut:

Tabel 2. Kriteria tingkat kesukaran butir soal

\begin{tabular}{c|c}
\hline $\begin{array}{c}\text { Indeks kesukaran } \\
(\mathrm{P})\end{array}$ & Keterangan \\
\hline $\mathrm{I} \leq 0,00$ & Terlalu sukar \\
$0,00<\mathrm{IK} \leq 0,30$ & Sukar \\
$0,30<\mathrm{IK} \leq 0,70$ & Sedang \\
$0,70<\mathrm{K} \leq 1,00$ & Mudah \\
$\mathrm{I} \leq 1,00$ & Terlalu mudah \\
\hline
\end{tabular}

\section{Daya Beda}

Menurut Arikunto (2013:228), untuk membedakan mana siswa yang mampu dan siswa yang kurang mampu menyelesaikan soal yang diujikan.

Uji dengan rumus sebagai berikut:

$$
\begin{aligned}
& \mathrm{D}=\text { daya pembeda beda soal } \\
& J_{A}=\text { banyaknya peserta kelompok atas } \\
& J_{B}=\text { banyaknya peserta kelas bawah } \\
& B_{A}=\text { banyaknya peserta kelompok atas yang } \\
& \quad \text { menjawab soal benar } \\
& B_{B}=\text { banyaknya peserta kelompok bawah } \\
& \quad \text { yang menjawab soal benar }
\end{aligned}
$$$$
\text { Keterangan: }
$$$$
\mathrm{D}=\frac{B_{A}}{J_{A}}-\frac{B_{B}}{J_{B}}
$$

Tabel 3. Kriteria daya pembebeda

\begin{tabular}{c|c}
\hline Daya pembeda & Keterangan \\
\hline $\mathrm{DP} \leq 0,00$ & Sangat jelek \\
$0,00<\mathrm{DP} \leq 0,20$ & Jelek \\
$0,20<\mathrm{DP} \leq 0,40$ & Cukup \\
$0,40<\mathrm{DP} \leq 0,70$ & Baik \\
$0,70<\mathrm{DP} \leq 1,00$ & Sangat baik \\
\hline
\end{tabular}

\section{Teknis Analisi Data \\ Uji Normalitas}

Uji normalitas yang digunakan adalah untuk mengetahui apakah data yang di peroleh dari hasil penelitian distribusi normal atau tidak. Uji normalitas dilakukan untuk mengetahui apakah pre-test dan post- test terdistribusi noarmal atau tidak. Uji normalitas dicari dengan mengunakan rumus Chi-kuadrat.

Keterangan:

$$
x^{2}=\sum_{i=1}^{k} \frac{\left(f_{o}-f_{h}\right)}{f h}
$$

$$
\begin{aligned}
& x^{2}=\text { chi kuadrat } \\
& f_{0}=\text { frekuensi yang diobservasi } \\
& f_{h}=\text { frekuensi yang diharapkan }
\end{aligned}
$$

kriteria: jika $x^{2}$ hitung $\leq x^{2}$ tabel dengan $\mathrm{dk}=$ k-1 dan $\alpha=5 \%$ maka data berdistribusi normal (Arikunto, 2013: 290).

\section{Uji Homogenitas}

Uji homogenitas adalah untuk mengetahui kesamaan varians. Pemngujian homogenitas sampel didasarkan pada asumsi bahwa apabila varians yang dimiliki oleh sampel-sampel tersebut cukup homogen (Arikunto, 2010:29). Jika $f_{\text {hitung }} \geq f_{\text {tabel }}$ maka sampel tidak homogenitas dan jika $f_{\text {hitung }} \leq f_{\text {tabel }}$ maka sampel homogen (Riduwan, 2008:9). Adapun persamaan varians tersebut sebagai berikut:

$$
F_{\text {hitung }}=\frac{\text { Varians terbesar }}{\text { Varians terkecil }}
$$

\section{Uji hipotesis}

Sebelum menguji hipotesis komperatif dua varuiabel yang berkorelasi, maka terlebih dahulu melakukan analisis tentang hubungan 
antara kedua saampel dengan mengunakan korelasi product mommen, yaitu:

$$
r_{x y}=\frac{\sum x y}{\sum x^{2} \sum y^{2}}
$$

Skor simpangan (deviation score ) didifinisikan sebagai selisih antara setiap skor seperangkat data dengan nilai rata pangkat data itu. Secara metamatis aljabar, difinisi tersebut di tulis sebagai berikut:

$$
\begin{aligned}
& X=X_{1}-\bar{X} \\
& Y=Y_{1}-\bar{Y}
\end{aligned}
$$

Untuk mencari rata-rata skor digunakan rumus sebagai berikut:

keterangan:

$$
\bar{x}=\frac{\sum x i}{n}
$$

$$
\begin{aligned}
& y_{1}=x_{1}=\text { skor simpangan } \\
& \mathrm{Y}_{1}=\mathrm{X}_{1}=\text { skor asli ( awal ) } \\
& \overline{\mathrm{Y}}=\bar{x} \text { rata-rata skor } \\
& \mathrm{n}=\text { jumlah data ( Furkam } \\
& \text { 2014:43 dalam Umam ) }
\end{aligned}
$$

Untuk menghitung ( Uji $t$ ) mengunakan rumus berpasangan/related

Keterangan:

$$
\mathrm{t}=\frac{\bar{x}_{1}-\bar{x}_{2}}{\sqrt{\frac{s_{1}^{2}}{n_{1}}+\frac{s_{2}^{2}}{n_{2}}-2 r\left(\frac{s_{1}}{\sqrt{n_{1}}}\right)\left(\frac{s_{2}}{\sqrt{n_{2}}}\right)}}
$$

$t=$ Nilai $t$ yang dihitung

$\bar{x}_{1}=$ Nilai rata-rata kelas eksperimen

$\bar{x}_{2}=$ nilai rata-rata kelas kontrol

$n_{1}=$ jumlah anggota kelas

eksperimen

$n_{2}=$ jumlah anggota kelas

kontrol

$S_{1}^{2}=$ varians kelas eksperimen

$S_{2}^{2}=$ varians kelas kontrol

$r=$ korelasi antara data dan

dua kelompok

jika anggota sampel $\mathrm{n}_{1}$ dan $\mathrm{n}_{2}$ varians homogen, maka digunakan dengan ketentuan

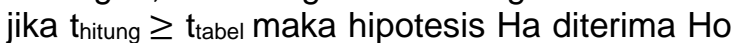

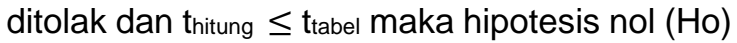
dan (Ha) ditolak ( Sugiyono, 2015:273 ).

\section{Uji N-gain}

Untuk mengetahui apakah peningkatan pemahaman konsep belajar siswa kelas eksperimen lebih baik dari kelas kontrol dilakukan dengan analisis skor gain ternomalisasi yang dihitung dengan mengunakan rumus sebagai berikut: Indeks gain $=\frac{\text { skor postest }- \text { skor pretest }}{\text { skor maksimun- } \text { skor pretest }}$

Tabel 4. Katagori Tingkat Gain

\begin{tabular}{c|c}
\hline Batasan & Kategori \\
\hline$g>$ & Tingga \\
$0,3<g \leq$ & Seda bng \\
$g \leq 0,3$ & Rendah \\
\hline & (Sugiyono, 2015:273)
\end{tabular}

\section{HASIL DAN PEMBAHASAN Hasil Penelitian}

Penelitian True Eksperimenntal Dasing ini telah dilaksanakan pada tanggal 24 Juni sampai dengan tanggal 23 Juli 2020 di SMPN 1 WERA pada kelas VII -1 sebagai kelas eksperimen berjumlah 21 orang dan kelas VII-2 sebagai kelas kontrol berjumlah 24 orang. Penelitian ini dilakukan dalam 4 kali pertemuan untuk masing-masing kelas sampel, dengan rincian 2 kali pertemuan dalam 4 jam pembelajaran untuk pre-terst dan post-test instrumen soal. Selanjutnya 2 kali pertemuan untuk kegiatan pelajaran.

\section{Hasil Studi Penelitian}

Hasil dari studi literatur dan studi lapangan, diketahui bahwa faktor penyebab ialah kendala dalam menggunakan media belajar yang sesuai dengan keadaan siswa. Seiring dengan perkembangan teknologi dan informasi yang semakin pesat, siswa pun mengikuti perkembangan tersebut, baik dalam lingkungan sosial maupun akademik. Siswa membutuhkan media belajar yang kreatif dan inovatif. Salah satu media yang cukup efektif untuk digunakan ialah media poster 3 dimensi. Poster 3 dimensi dapat dimanfaatkan sebagai media dalam pembelajaran IPA. Sementara di kelas VII SMPN 1 WERA pada tahun pelajaran 2019/2020 belum menggunakan media poster dalam kegiatan belajar mengajar, khususnya pada materi tata surya.

\section{Hasil Uji Coba Instrumen \\ Uji Validitas}

1. Pre-Test

Sebelum soal tes diberikan kepada siswa, terlebih dahulu dilakukan uji validitas terhadap soal yang akan diuji agar mengetahui soal tersebut layak digunakan dalam penelitian. Dari hasil yang dilakukan pada kelas IX SMPN 1 WERA yang pernah belajar materi tata surya dengan jumlah siswa 28 orang. Adapun dari 30 soal diperoleh 24 soal yang termaksud kategori valid, 6 soal yang kategori invalid.

\section{Post-Tes}

Sebelum soal tes diberikan terahadap siswa, terlebih dahulu dilakukan uji validitas terhadap soal yang akan diuji agar mengetahui soal tersebut layak digunakan dalam penelitian. Berdasarkan hasil yang dilakukan pada kelas IX SMPN 1 WERA yang pernah belajar materi tata surya dengan jumlah siswa 28 orang. Dari 30 soal diperoleh 24 yang termaksud kategori valid, 6 soal yang kategori invalid.

\section{Uji Reabilitas Instrumen}

1. Pre-Test 
Uji coba reliabilitas dilakukan pada 30 soal dengan menggunakan rumus KR20 diperoleh nilai $r_{11}$ sebesar 0,911 dan nilai $r_{\text {tabel }}$ untuk taraf sigmifikan 5\% dengan $\mathrm{N}=28$ orang sehingga diperoleh nilai 0,374 . Oleh karena itu, $r_{\text {hitung }}$ lebih besar daripada $r_{11}$ $(0,911>0,374)$. Maka instrumen penelitian ini memiliki tingkat realibilitas yang yang kuat atau tinggi.

\section{Post-Test}

Uji coba reliabilitas dilakukan pada 30 soal dengan menggunakan rumus KR20 diperoleh nilai $r_{11}$ sebesar 0,911 dan nilai $r_{\text {tabel }}$ untuk taraf signifikan $5 \%$ dengan $\mathrm{N}=28$ orang sehingga diperoleh nilai 0,374 Oleh

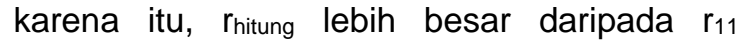
$(0,911>0,374)$. Maka instrumen penelitian ini memiliki tingkat realibilitas yang yang kuat atau tinggi.

\section{Tingkat Kesukaran}

\section{Pre-Test}

Uji coba tingkat kesukaran soal bermaksud untuk mengetahui tingkat perbedaan soal yang akan diberikan terhadap siswa. Berdasarkan hasil uji tingkat kesukaran soal, diketahui bahwa soal dengan kriteria mudah 6 soal karena berada pada rentang $0,70<\mathrm{IK} \leq 1,00$, soal dengan kriteria terlalu mudah 1 soal karena berada pada rentang $\mathrm{IK}<1,00$, soal dengan kriteria sedang 18 soal karena berada pada rentang $0,30<1 \mathrm{~K} \leq 0,70$, soal dengan kriteria sukar 4 soal karena barada pada rentang $0,00<\mathrm{IK} \leq 0,30$, dan soal yang berkriteria terlalu sukar 1 soal dengan rentang $\mid \mathrm{K}<0,00$.

\section{Post-Tes}

Uji coba tingkat kesukaran soal bermaksud untuk mengetahui tingkat perbedaan soal yang akan diberikan terhadap siswa. Berdasarkan hasil uji tingkat kesukaran soal, diketahui bahwa soal dengan kriteria mudah 6 soal karena berada pada rentang $0,70<\mathrm{IK} \leq 1,00$, soal dengan kriteria terlalu mudah 1 soal karena berada pada rentang $\mathrm{IK}<1,00$, soal dengan kriteria sedang 18 soal karena berada pada rentang $0,30<1 \mathrm{~K} \leq 0,70$, soal dengan kriteria sukar 4 soal karena barada pada rentang $0,00<\mid \mathrm{K} \leq 0,30$, dan soal yang berkriteria terlalu sukar 1 soal dengan rentang $\mid \mathrm{K}<0,00$.

\section{Uji Daya Beda \\ 1. Pre-Test}

Berdasarkan uji daya beda soal, dapat disimpulkan bahwa soal yang memiliki daya pembeda sangat jelek yakni 4 soal karena berada pada rentang $\mathrm{DP} \leq 0,00$. Soal yang memiliki daya pembeda jelek 1 soal $0,00<\mathrm{DP} \leq 0,20$ soal karena berada pada rentang $0,20<D P \leq 0,40$. Soal yang memiliki daya pembeda cukup 3 soal karena berada pada rentang $0,40<\mathrm{DP} \leq 0,70$, dan soal yang memiliki daya pembeda baik 22 soal karena berada pada rentang $0,40<D P \leq 0,70$.

\section{Post-Tes}

Berdasarkan uji daya beda soal, dapat disimpulkan bahwa soal yang memiliki daya pembeda sangat jelek yakni 4 soal karena berada pada rentang $\mathrm{DP} \leq 0,00$, soal yang memiliki daya pembeda jelek 1 soal $0,00<\mathrm{DP} \leq 0,20$ soal karena berada pada rentang $0,20<D P \leq 0,40$, soal yang memiliki daya pembeda cukup 3 soal karena berada pada rentang $0,40<\mathrm{DP} \leq 0,70$, dan soal yang memiliki daya pembeda baik 22 soal soal karena berada pada rentang $0,40<D P \leq 0,70$.

Tabel 5. Rangkuman akhir uji instrumen

\begin{tabular}{|c|c|}
\hline Jenis uji & Jenis instrumen soal \\
\hline Uji validitas & $\begin{array}{l}\text { Soal : } 30 \text { pre-test dan } \\
30 \text { pos-test. } \\
\text { pre-test: } 24 \text { Valid , } 6 \\
\text { invalid. } \\
\text { post-test: } 24 \text { Valid, } 6 \\
\text { invalid. }\end{array}$ \\
\hline Uji reabilitas & $\begin{array}{l}\text { Reliabel : } 30 \text { pre-test } \\
\text { dan } 30 \text { pos-test }\end{array}$ \\
\hline Uji taraf kesukaran & $\begin{array}{l}\text { pre-test: sedang } 18, \\
\text { mudah } 6 \text {, terlalu } \\
\text { mudah } 1 \text {, sukar } 4 \text {, } \\
\text { terlalu sukar } 1 \text {. } \\
\text { Post-test : sedang } \\
18, \text { mudah } 6 \text {, terlalu } \\
\text { mudah } 1 \text {, sukar } 4 \text {, } \\
\text { terlalu sukar } 1 .\end{array}$ \\
\hline Uji daya pembeda & $\begin{array}{l}\text { pre-test : sangat } \\
\text { jelek 4, jelek 1, } \\
\text { cukup 3, baik 22 } \\
\text { post-test : sangat } \\
\text { jelek 4, jelek 1, } \\
\text { cukup 3, baik 22 }\end{array}$ \\
\hline
\end{tabular}

\section{Hasil Analisis Data Hasil Penelitian Hasil Pre-Test}

Pre-test atau tes kemampuan awal untuk instrumen yang berupa soal-soal dilakukan pada kedua sampel kelas eksperimen dan kelas kontrol. Hasil pre-test tersebut dapat dilihat pada tabel 6 sebagai berikut.

\begin{tabular}{ccccc}
\multicolumn{5}{c}{ Tabel 6. data pre-test } \\
\hline Kelas & $\begin{array}{c}\text { Jumla } \\
\text { h } \\
\text { siswa }\end{array}$ & $\begin{array}{c}\text { Nilai } \\
\text { terting } \\
\text { gi }\end{array}$ & $\begin{array}{c}\text { Nilai } \\
\text { terenda } \\
\text { h }\end{array}$ & $\begin{array}{c}\text { Rata- } \\
\text { rata } \\
\text { nilai }\end{array}$ \\
\hline $\begin{array}{c}\text { Eksprime } \\
\mathrm{n}\end{array}$ & 21 & 75 & 30 & $\begin{array}{c}50,23 \\
8\end{array}$ \\
Kontrol & 24 & 70 & 35 & $\begin{array}{c}51,45 \\
8\end{array}$ \\
\hline
\end{tabular}

\section{Hasil Post-Test}

Tes akhir post-test juga diberikan kudua sampel dengan menggunakan instrumen soal 
yang sudah di pelajari oleh siswa. Hasil posttest yang diperoleh untuk kelas eksperimen dan kelas kontrol dapat dilihat pada tabel 7 sebagai berikut.

Tabel 7. data post-test

\begin{tabular}{ccccc}
\hline Kelas & $\begin{array}{c}\text { Jumla } \\
\mathrm{h} \\
\text { siswa }\end{array}$ & $\begin{array}{c}\text { Nilai } \\
\text { terting } \\
\text { gi }\end{array}$ & $\begin{array}{c}\text { Nilai } \\
\text { terend } \\
\text { ah }\end{array}$ & $\begin{array}{c}\text { Rata- } \\
\text { rata } \\
\text { nilai }\end{array}$ \\
\hline $\begin{array}{c}\text { Eksprim } \\
\text { en }\end{array}$ & 21 & 90 & 50 & $\begin{array}{c}72,14 \\
2\end{array}$ \\
Kontrol & 24 & 80 & 45 & $\begin{array}{c}62,29 \\
1\end{array}$ \\
\hline
\end{tabular}

dari hasil pre-test dan post-test di atas dapat di tabulasikan peningkatanya dalam tabel 8 tentang rangkuman nilai pre-test dan post-test kedua sampel tersebut.

Tabel 8. Rangkuman nilai pre-test dan posttes kedua sampel.

\begin{tabular}{ccc}
\hline \multirow{2}{*}{ Kelas } & \multicolumn{2}{c}{ Rata-rata nilai } \\
\cline { 2 - 3 } & pre-test & post-tes \\
\hline Eksperimen & 50,238 & 72,142 \\
Kontrol & 51,456 & 62,291 \\
\hline Berdasarkan data & nilai & rata-rata kedua
\end{tabular}
kelas yang telah diperoleh, dapat dibuat diagram peningkatan pemahaman konsep fisika siswa seperti gambar 1 di bawah ini.

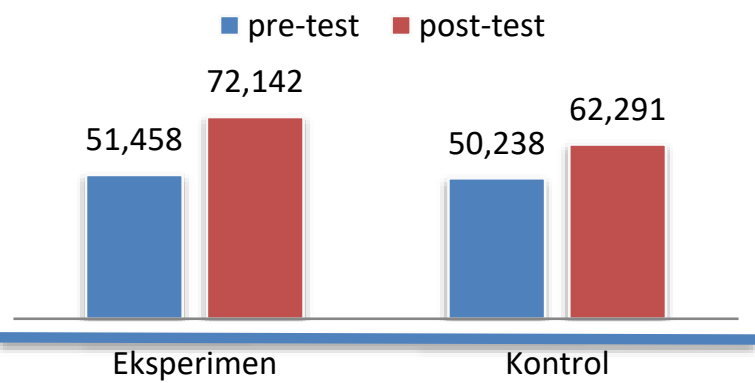

Gambar 1. diagram peningkatan pemahaman konsep fisika siswa

Tabel 9. Ringkasan pemahaman konsep fisika siswa kelas eksperimen dan kelas kontrol pada siswa kelas VII SMPN 1 WERA.

\begin{tabular}{lllll}
\hline Diskripsi & \multicolumn{2}{l}{$\begin{array}{l}\text { Kelas } \\
\text { Eksperiman } \\
\end{array}$} & $\begin{array}{l}\text { Kelas kontrol } \\
\mathrm{N}=21\end{array}$ & \\
& $\begin{array}{l}\text { Pre- } \\
\text { test }\end{array}$ & $\begin{array}{l}\text { Post- } \\
\text { test }\end{array}$ & $\begin{array}{l}\text { Pre- } \\
\text { test }\end{array}$ & $\begin{array}{l}\text { Post- } \\
\text { test }\end{array}$ \\
\hline Rata-rata & 50,23 & 72,14 & 51,45 & 62,29 \\
& 8 & 2 & 8 & 1 \\
\hline $\begin{array}{l}\text { Standar } \\
\text { deviasi }\end{array}$ & 13,36 & 11,37 & 11,37 & 11 \\
$\begin{array}{l}\text { (S) } \\
\text { Skor }\end{array}$ & 2 & 1 & 1 & \\
$\begin{array}{l}\text { maksimu } \\
\text { m teoritis }\end{array}$ & 100 & 100 & 100 & 100 \\
\hline $\begin{array}{l}\text { Skor } \\
\text { minimum } \\
\text { teoritis }\end{array}$ & 0 & 0 & 0 & 0 \\
\hline
\end{tabular}

\begin{tabular}{lllll}
\hline $\begin{array}{l}\text { Skor } \\
\text { maksimu } \\
\mathrm{m}\end{array}$ & 75 & 90 & 70 & 80 \\
\hline $\begin{array}{l}\text { Skor } \\
\text { minimum }\end{array}$ & 30 & 45 & & \\
\hline Tuntas & 9,52 & 47,62 & $0 \%$ & 20,83 \\
& $\%$ & $\%$ & & $\%$ \\
\hline $\begin{array}{l}\text { Tidak } \\
\text { tuntas }\end{array}$ & 90,48 & 52,38 & 100 & $25 \%$ \\
\hline $\begin{array}{l}\text { Peningkat } \\
\text { an } \\
\text { ketuntasa }\end{array}$ & $38,09 \%$ & & $20,83 \%$ \\
$n$
\end{tabular}

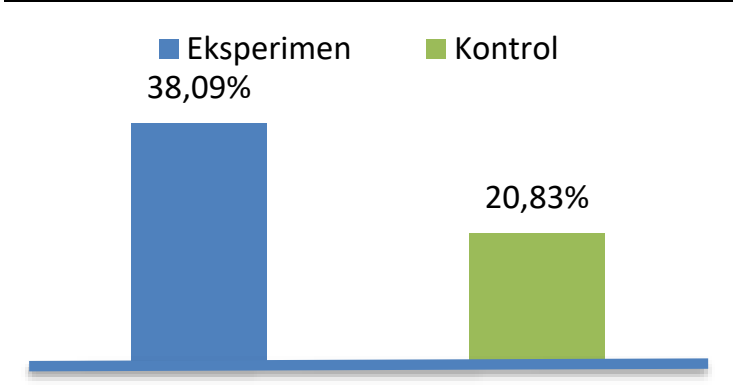

Kelas Eksperimen dan Kelas Kontrol

Gambar 2. Diagram peningkatan pemahaman konsep fisika siswa

\section{Analisis Data Hasil Belajar Uji Homogenitas}

Uji homogenitas dilakukan untik mengetahui apakah kemampuan awal kedua sampel yang menjadi objek penelitian bersifat homogen atau tidak. Sehingga pada uji homogenitas digunakan data pre-test siswa. Berdasarkan berdasarkan hasil penelitian, diperoleh hasil seperti pada tabel 10 di bawah ini tentang uji homogenitas pre-test.

Tabel 10. Uji homogenitas pre-test.

\begin{tabular}{|c|c|c|c|c|c|}
\hline Kelas & $\begin{array}{l}\text { Rata- } \\
\text { rata } \\
\text { nilai }\end{array}$ & Varians & $F_{\text {hitung }}$ & $F_{\text {tabel }}$ & Keterangar \\
\hline ksperimen & 50,238 & 218,69 & 1,70 & 2 , & Homogen \\
\hline Kontrol & 51,456 & 129,302 & & 04 & Homogen \\
\hline
\end{tabular}
homogenitas pre-test sampel, diperoleh $F_{\text {hitung }}=1,7$ dan $F_{\text {tabel }}=2,04$ pada taraf signifikan $5 \%$ berdasarkan kriteria penguji. Jika $F_{\text {hitung }}<$ $F_{\text {tabel maka sampel tersebut dikatakan }}$ homogen. Dengan demikian, bahwa kedua sampel kelas eksperimen daan kelas kontrol memiliki kemampuan yang homogenitas.

Tabel 11. Uji homogenitas post-tes

\begin{tabular}{cccccc}
\hline Kelas & $\begin{array}{c}\text { Rat } \\
\text { a- }\end{array}$ & $\begin{array}{c}\text { Varia } \\
\text { ns }\end{array}$ & $\begin{array}{c}\mathrm{F}_{\text {hit }} \\
\text { ung }\end{array}$ & $\begin{array}{c}\mathrm{F}_{\text {ta }} \\
\text { bel }\end{array}$ & $\begin{array}{c}\text { Ketera } \\
\text { ngan }\end{array}$ \\
\hline
\end{tabular}




\begin{tabular}{|c|c|c|c|c|c|}
\hline & $\begin{array}{l}\text { rata } \\
\text { nilai }\end{array}$ & & & & \\
\hline $\begin{array}{c}\text { Eksperi } \\
\text { men }\end{array}$ & $\begin{array}{c}72,1 \\
47\end{array}$ & $\begin{array}{l}183, \\
598 \\
\end{array}$ & \multirow[t]{2}{*}{$\begin{array}{c}1,4 \\
1\end{array}$} & \multirow[t]{2}{*}{$\begin{array}{l}2, \\
04\end{array}$} & $\begin{array}{c}\text { Homog } \\
\text { en }\end{array}$ \\
\hline Kontrol & $\begin{array}{c}62,2 \\
91\end{array}$ & $\begin{array}{l}130, \\
389\end{array}$ & & & $\begin{array}{c}\text { Homog } \\
\text { en }\end{array}$ \\
\hline
\end{tabular}
homogenitas pre-test sampel diperoleh $F_{\text {hitung }}=1,41$ dan $F_{\text {tabel }}=2,04$ pada taraf signifikan $5 \%$ berdasarkan kriteria penguji. Jika $F_{\text {hitung }}<F_{\text {tabel }}$ maka sampel tersebut dikatakan homogen. Dengan demikian, bahwa kedua sampel kelas eksperimen dan kelaas kontrol memiliki kemampuan yang homogenitas.

\section{Uji Normalitas}

Berdasarkan hasil pre-test dan post-test, dilakukan uji normalitas untuk mengetahui distribusi hasil yang diperoleh. Berikut ini disajikan uji normalitas yang dilakukan pada masing-masing kelompok.

Tabel 12. Uji Normalitas data pre-test

\begin{tabular}{cccc}
\hline Kelas & $\mathrm{X}^{2}$ hitung & $\mathrm{X}^{2}$ tabel & Keterangan \\
\cline { 1 - 2 } Eksperimen & 5,598 & 11, & Terdistribusi \\
\cline { 1 - 2 } Kontrol & 6,661 & 070 & Normal \\
\hline
\end{tabular}

Berdasarkan hasil perhitungan pada kelas eksperimen diperoleh $x^{2}$ hitung $=5,598$ dan $\mathrm{X}^{2}$ tabel 11,070 dengan taraf signifakan 5\% berdasarkan kriteria penguji. Jika $\mathrm{X}^{2}$ hitung $<\mathrm{X}^{2}$ tabel maka data tersebut terdistribusi normal. Dengan demikian, hasil pre-test kelas eksperimen tersebut terdistribusi normal.

Pada kelas kontrol berdasarkan hasil perhitungan diperoleh $\mathrm{x}^{2}$ hitung $=6,661$ dan $\mathrm{X}^{2}$ tabel 11,070 dengan taraf signifakan 5\% berdasarkan kriteria penguji. Jika $\mathrm{X}^{2}$ hitung $<\mathrm{X}^{2}$ tabel maka data tersebut terdistribusi normal. Dengan demikian, hasil pre-test kelas eksperimen terseebut terdistribusi normal.

Tabel 13. Uji Normalitas data post-test

\begin{tabular}{cccc}
\hline Kelas & $\mathrm{X}^{2}{ }_{\text {hitung }}$ & $\mathrm{X}^{2}$ tabel & Keterangan \\
\cline { 1 - 2 } Eksperimen & 3,446 & 11, & Terdistribusi \\
\cline { 1 - 2 } Kontrol & 3,568 & 070 & Normal \\
\cline { 1 - 2 }
\end{tabular}

Pada kelas eksperimen berdasarkan hasil perhitungan diperoleh $x^{2}$ hitung $=3,446$ dan $\mathrm{X}^{2}$ tabel 11,070 dengan taraf signifakan $5 \%$ berdasarkan kriteria penguji. Jika $\mathrm{X}^{2}$ hitung $<\mathrm{X}^{2}$ tabel maka data tersebut terdistribusi normal. Dengan demikian, hasil pre-test kelas eksperimen terseebut terdistribusi normal.

\section{Uji hipotesis ( Uji-t )}

Uji hipotesis dilakukan untuk mengetahui apakah ada peningkatan pemahaman konsep siswa dengan melihat efektifitas penggunaan media poster 3 dimensi secara daring pada materi tata surya berbasis google classroom dan membuktikan ada atau tidaknya peningkatan pemahaman konsep siswa. Hal itu dilakukan dengan melihat pada pembelajaran yang menggunakan media poster 3 dimensi secara daring pada materi tata surya berbasis google classroom dan pembelajaran yang tidak menggunakan media perlu diuji statistik dengan uji-t berkorelasi ( ralate). Berdasarkan hasil penelitian yang dilakukan, diperoleh hasil sebagaimana pada tabel 4.10 tentang uji hipotesis menggunakan data pre-test .

Tabel 14. Hasil Uji Hipotesis Menggunakan Data Pre-Test.

\begin{tabular}{|c|c|c|c|c|c|}
\hline Kelas & $\begin{array}{l}\text { Juml } \\
\text { ah } \\
\text { sisw } \\
\text { a }\end{array}$ & $\begin{array}{l}\text { Rata } \\
\text {-rata }\end{array}$ & $\begin{array}{c}\text { Rerat } \\
\text { an } \\
\text { varia } \\
\mathrm{ns} \mathrm{S}^{2}{ }^{2}\end{array}$ & $\begin{array}{c}\text { thitun } \\
\mathrm{g}\end{array}$ & $t_{\text {tabel }}$ \\
\hline $\begin{array}{c}\text { Eksperi } \\
\text { men }\end{array}$ & 21 & $\begin{array}{c}50,2 \\
38 \\
\end{array}$ & $\begin{array}{c}218,6 \\
84\end{array}$ & \multirow{2}{*}{$\begin{array}{c}- \\
0,3 \\
32\end{array}$} & \multirow[t]{2}{*}{$\begin{array}{l}1,6 \\
82\end{array}$} \\
\hline Kontrol & 24 & $\begin{array}{c}51,4 \\
58\end{array}$ & $\begin{array}{c}129,2 \\
99\end{array}$ & & \\
\hline
\end{tabular}

Berdasarkan hasil perhitungan pre-test diperoleh nilai thitung $=-0,332$. Dari hipotesis tersebut dapat digunakan kaidah pengujian dua pihak ( thitung >ttabe) dan diperoleh tabel=1,682 pada taraf signifakan $5 \%$. Itu berarti thitung $>$ tabel $(-0,332<1,682)$ merupakan hipotesis nol $(\mathrm{Ho})$ diterima dan hipotesis alternatif $(\mathrm{Ha})$ ditolak sehingga tidak terdapat perbedaan pada kemampuan awal siswa.

Tabel 15. Hasil Uji Hipotesis Menggunakan Data Post-Test.

\begin{tabular}{|c|c|c|c|c|c|}
\hline Kelas & $\begin{array}{c}\text { Juml } \\
\text { ah } \\
\text { sisw } \\
\text { a }\end{array}$ & $\begin{array}{l}\text { Rata } \\
\text {-rata }\end{array}$ & $\begin{array}{c}\text { Rerat } \\
\text { an } \\
\text { varia } \\
\mathrm{ns} \mathrm{S}^{2}{ }^{2}\end{array}$ & $\begin{array}{c}\text { thitun } \\
\mathrm{g}\end{array}$ & $t_{\text {tabel }}$ \\
\hline $\begin{array}{c}\text { Eksperi } \\
\text { men }\end{array}$ & 21 & $\begin{array}{c}72,1 \\
42\end{array}$ & $\begin{array}{c}178,5 \\
43\end{array}$ & $\begin{array}{r}2,7 \\
44\end{array}$ & $\begin{array}{l}1,6 \\
82\end{array}$ \\
\hline Kontrol & 24 & $\begin{array}{c}62,2 \\
91\end{array}$ & 121 & & \\
\hline
\end{tabular}

Berdasarkan hasil perhitungan pre-test diperoleh nilai thitung $=-2,744$ dari hipotesis tersebut, maka dapat digunakan kaidah pengujian dua pihak ( thitung $>t_{\text {tabe }}$ ) diperoleh $t_{\text {tabel }}=1,682$ pada taraf signifakan $5 \%$. Hal itu berarti thitung $>$ tabe $(2,744>1,682)$ merupakan hipotesis alternatif $(\mathrm{Ha})$ diterima dan hipotesis nol (Ho) ditolak. Dapat disimpulkan dalam penelitian ini bahwa ada peningkatan ketika menggunakan media poster 3 dimensi secara daring pada materi tata surya berbasis google classroom untuk meningkatkan pemahaman konsep fisika siswa kelas VII SMPN 1 WERA tahun ajaran 2019/2020.

\section{Uji N-Gain}

Uji N-gain digunakan untuk mengatahui derajat peningkatan pemahan konsep siswa. Hasil perhitungan $\mathrm{N}$-gain dapat dilihat pada tabel 16 sebegai bebrikut:

Tabel 16. Uji N-gain nilai pre-test dan posttest kedua sampel 


\begin{tabular}{cccc}
\hline No & Kelas & $\mathrm{N}<\mathrm{G}>$ & $\begin{array}{c}\text { Kategori } \\
\text { peningkatan }\end{array}$ \\
\hline 1 & Eksprimen & 0,44 & Sedang \\
\hline 2 & Kontrol & 0,22 & Rendah \\
\hline
\end{tabular}

Berdasarkan hasil analisis nilai uji $\mathrm{N}$ gain sebelumnya memiliki perbedaan di kedua kelas. Perbedaan hasil N-gain tersebut memiliki kategori yang berbeda yaitu untuk kelas eksperimen sebesar 0,44 dan berarti kategori "sedang". Sementara yang diajarkan dengan menggunakan media poster 3 dimensi secara daring pada materi tata surya berbasis google classroom, sedangkan untuk kelas kontrol sebesar 0,22 berkategori "rendah" yang diajarkan dengan model pembelajaran tanpa media.

\section{Eksperimen}

\section{0,44}

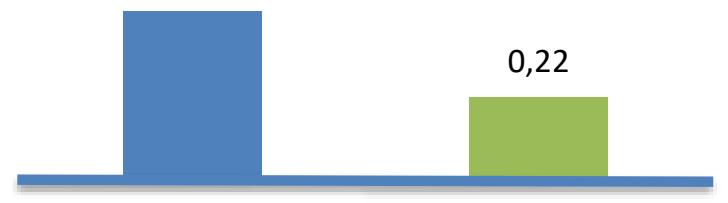

Kelas Eksperimen dan Kelas Kontrol

Gambar 3. Diagram N-gain pemahaman konsep fisika siswa.

\section{Pembahasan}

Dalam penelitian ini, peneliti melihat dari siswa yang kurang tanggap memahami konsep fisika, khususnya pada materi tata surya. Hal itu dikarenakan masih digunakanannya metode ceramah dan hafalan atau model pembelajaran tanpa media. Berdasarkan permasalahan tersebut, perlu dilakukan inovasi pada pembelajaran IPA, khususnya fisika pada materi tata surya di kelas VII SMPN 1 WERA. Sehingga perlu menggunakan media pembelajaran yang dapat meningkatkan pemahaman konsep siswa. Solusinya yaitu dengan menggunakan media poster 3 dimensi secara daring pada materi tata surya berbasis google classroom.

Dalam penentuan kelas yang akan dijadikan sampel, peneliti melakukan uji homogenitas. Dari hasil uji homogenitas pada kelas VII-1 dan VII-2 hasilnya sama-sama homogen. Sehingga peneliti mengambil sampel di kelas VII-1 dijadikan sebagai kelas eksperimen dan kelas VII-2 dijadikan sebagai kelas kontrol.

Berdasarkan perbandingan peningkatan pemahaman konsep siswa antara kelas yang diajarkan dengan menggunakan media poster 3 dimensi secara daring pada materi tata surya berbasis google classroom (kelas eksperimen) dan kelas yang tidak diajarkan dengan media atau tanpa menggunakan media (kontrol) Dapat disimpulkan bahwa hipotesis yang diajukan dapat diterima. Bahwa terdapat pengaruh terhadap penggunaan media poster 3 dimensi secara daring pada materi tata surya berbasis google classroom. Selain itu, terdapat pemahaman konsep fisika siswa berdasarkan kriteria penguji hipotesis statistik. Maka kesimpulannya ialah thitung $>$ tabel $(2,744>1,682)$ berarti bahwa hipotesis alternatif $(\mathrm{Ha})$ diterima dan hipotesis nol statistik (Ho) ditolak. Peningkatan pemahaman konsep fisika siswa sebelum diberikan perlakuan dibandingkan setelah diberikan perlakuan.

\section{SIMPULAN}

Berdasarkan hal-hal yang dikemukakan pada halaman sebelumnya. Dari hasil perhitungan tabel dan uji hipotesis statistik (uji-t) untuk kelas eksperimen dengan nilai posttest thitung $=2,744$ dan $t_{\text {tabel }}=1,682$ (thitung $>t_{\text {tabel }}$ ) yang menujukkan hipotesis nol (Ho) ditolak hipotesis alternatif $(\mathrm{Ha})$ diterima.

Hasil analisis nilai uji $\mathrm{N}$-gain sebelumnya memiliki perbedaan di kedua kelas. Perbedaan hasil N-gain tersebut memiliki kategori yang berbeda yaitu untuk kelas eksperimen sebesar 0,44 dan berarti kategori "sedang". Sementara yang diajarkan dengan menggunakan media poster 3 dimensi secara daring pada materi tata surya berbasis google classroom, sedangkan untuk kelas kontrol sebesar 0,22 berkategori "rendah" yang diajarkan dengan pembelajaran tanpa menggunakan media.

Sehingga dapat disimpulkan bahwa efektifitas penggunaan media poster 3 dimensi secara daring pada materi tata surya berbasis google classroom untuk meningkatkan pemahaman konsep fisika siswa kelas VII SMPN 1 WERA tahun ajaran 2019/2020, terdapat pengaruh signifikan.

\section{DAFTAR RUJUKAN}

Amalia, I. S. (2013). Evaluation of Hypertension Poster to Talaga Public Health Visitors, Majalengka District. Kemas Jurnal Kesehatan Masyarakat.

Arikunto, S. (2012). Prosedur Penelitian : Suatu Pendekatan Praktik (Edisi Revisi). In Rineka Cipta.

Azhar, A. (2008). Media pembelajaran; Edisi revisi. In Repositori Riset Kesehatan Nasional.

Dahar, R. W. (2011). Teori-teori Belajar dan Pembelajaran. Erlangga.

Darmayanti, N. W. S., \& Zulkarnain, Z. (2018). PEMBERIAN PENGAYAAN MATERI PELAJARAN FISIKA UNTUK SISWA MELALUI KEGIATAN BIMBINGAN BELAJAR DI LUAR JAM SEKOLAH DI DESA GONTORAN, KECAMATAN 
$\begin{array}{lcr}\text { LINGSAR, } & \text { LOMBOK } & \text { BARAT. } \\ \text { SELAPARANG } & \text { Jurnal } & \begin{array}{r}\text { Pengabdian } \\ \text { Merkyarakat }\end{array}\end{array}$ https://doi.org/10.31764/jpmb.v1i2.454

Daryanto. (2015). Media Pembelajaran. Satu Nusa.

Isnaini, M., Ramlah, R., \& Erwinta, E. S. (2018). IDENTIFIKASI KETERAMPILAN PROSES SAINS SISWA MAN 2 KOTA MATARAM KELAS XI-A MATA PELAJARAN FISIKA TAHUN 2017. KONSTAN - JURNAL FISIKA DAN PENDIDIKAN FISIKA. https://doi.org/10.20414/konstan.v3i1.6

Jannah, F. Z., Serevina, V., \& Astra, M. (2016). PENGEMBANGAN MEDIA PEMBELAJARAN POSTER FISIKA FLUIDA STATIS BERBASIS LINGKUNGKAN DALAM BENTUK POSTER PHOTOSCRAP. https://doi.org/10.21009/0305010204

MAIYENA, S. (2016). PENGEMBANGAN MEDIA POSTER BERBASIS PENDIDIKAN KARAKTER UNTUK MATERI GLOBAL WARMING. Ta'dib. https://doi.org/10.31958/jt.v17i2.269

Triyani, L., Islahudin, I., \& Darmayanti, N. W. S. (2019). PENGEMBANGAN MEDIA PEMBELAJARAN KALSEG FISIKA UNTUK MENINGKATKAN PEMAHAMN KONSEP SISWA KELAS X MATERI USAHA. ORBITA: Jurnal Kajian, Inovasi Dan Aplikasi Pendidikan Fisika. https://doi.org/10.31764/orbita.v5i1.897

Utami, L. S., \& Darmayanti, N. W. . (2019). EFEKTIFITAS PEMBELAJARAN MULTIREPRESENTASI UNTUK MENINGKATKAN PEMAHAMAN KONSEP MAHASISWA FISIKA MATERI GELOMBANG DAN OPTIK TAHUN AKADEMIK 2018/2019. ORBITA: Jurnal Kajian, Inovasi Dan Aplikasi Pendidikan Fisika.

https://doi.org/10.31764/orbita.v5i1.1028

Zaman, B. (2013). Media dan Sumber Belajar TK Cet. 5. Universitas Terbuka. 